\title{
DINAMIKA PENYELESAIAN SENGKETA LINGKUNGAN HIDUP DI INDONESIA
}

\author{
Oleh : \\ Selamet Suhartono*
}

\begin{abstract}
Any solution to the environment in Indonesia is very dynamic in line with the development: UULH (the law on the environment) was regulated through the court channel and tripartite institutions, UUPLH (the law on the environmental management), through the court and out of cour channels, namely the institution with an authotiry to decide and not to decide but the forms of the institutions are not clearly mentioned, namely arbitration and mediation which is clearly stated. The use of the court channels is based on the choices made by parties, and it is marely solved through the court if this kind of solution is stated to be wrong by one two parties.
\end{abstract}

Kata Kunci: sengketa lingkungan, pengadilan, luar pengadilan.

\section{PENDAHULUAN}

Pembangunan pada dasarnya merupakan sebuah proses perubahan yang terus-menerus untuk mencapai tujuan yang telah ditetapkan, dengan memanfaatkan sumber daya alam dan lingkungan hidup yang tersedia. Dalam konteks pembangunan di Indonesia, tujuan tersebut diarahkan untuk mewujudkan masyarakat yang adil, makmur, dan sejahtera, sebagamana diamanatkan di dalam Pembukaan Undang Undang Dasar 1945 alinea IV, yang tercermin dalam kalimat "...untuk memajukan kesejahteraan umum, mencerdaskan kehidupan bangsa, dan ikut melaksanakan ketertiban dunia berdasarkan perdamaian abadi"2.

Sehubungan dengan pengertian konsep pembangunan yang demikian, maka setiap proses

${ }^{1}$ Slamet Suhartono, adalah Dosen Tetap Yayasan Perguruan 17 Agustus 1945 Surabaya yang ditempatkan pada Fakultas Hukum Universitas 17 Agustus 1945 Surabaya.

${ }^{2}$ Baca selengkapnya di dalam Pembukaan Undang Undang Dasar 1945 alinea keempat. kegiatan pembangunan selalu dihadapkan pada persoalan-persoalan yang dilematis, di satu sisi pembangunan harus memanfaatkan dan mengolah sumber daya alam dan lingkungan, untuk pemenuhan kebutuhan hidup dalam rangka meningkatkan kesejahteraan masyarakat yang terus meningkat, tetapi pada sisi yang lain, manusia dituntut untuk tetap mempertahankan dan melestarikan fungsifungsi lingkungan sebagai penopang kehidupan makluk hidup dimuka bumi, termasuk manusia. Tidak mudah melakukan atau mengerjakan dua hal yang bertolak belakang secara bersama-sama, mengutamakan salah satu kepentingan, menyebabkan terabaikannya kepentingan yang lain, mengutamakan kelestarian lingkungan, maka kesejahteraan akan terabaikan, tetapi apabila mengedepankan kesejahteraan masyarakat dengan menomor duakan kelestarian lingkungan, akan menimbulkan malapetaka ekologis yang mengerikan. 
Pengutamaan sektor industri sebagai pilihan kebijakan dalam percepatan pencapaian tujuan pembangunan, memang memberikan dampak positif bagi masyarakat, tetapi pada sisi yang lain pembangunan sektor industri membawa rangkaian permasalahan yang sangat kompleks, dan permasalahan ini, apabila tidak dikendalikan dengan baik akan sangat merugikan kehidupan masyarakat. Dampak negatif pembangunan industri terutama terkait dengan limbah yang dihasilkan oleh proses produksi barang-barang industri, yang pada umumnya dalam bentuk kerusakan dan/atau pencemaran lingkungan hidup. Pencemaran lingkungan hidup merupakan dampak samping dari kegiatan industri yang lebih banyak disebabkan oleh kesalahan dalam melakukan kegiatan indistri dan pengelolaan limbah usaha yang tidak sesuai dengan persyaratan yang telah ditentukan, seperti pembuangan limbah gas, limbah cair, maupun limbah udara yang tidak memenuhi standar ketentuan yang telah disyaratkan, misalnya melanggar baku mutu, sehingga menimbulkan dampak negatif yang sangat merugikan lingkungan hidup.

Pencemaran dan atau kerusakan lingkungan sebagai dampak negative dari kegiatan industri, akhir-akhir ini semakin mengkhawatirkan seiring dengan meningkatnya kuantitas penggunaan teknologi industri oleh umat manusia. Pencemaran dan kerusakan lingkungan telah mengancam ekosistem bumi, bahkan dalam jangka panjang dapat menyebabkan krisis ekologi. Krisis ekologi ini bukan lagi merupakan kemungkinan masa depan, tetapi sudah merupakan kenyataan yang tidak mungkin dapat dihindarkan ${ }^{3}$. Pendapat di atas menunjukkan, bahwa ancaman terjadinya kerusakan ekologi bukan lagi sebagai ilusi, dan fantasi, melainkan sebagai sesuatu yang nyata dan terjadi. Kerusakan dan pencemaran lingkungan melanggar hak masyarakat atas kenikmatan lingkungan hidupnya yang baik dan sehat, bahkan dapat merugikan masyarakat, baik secara ekologis maupun secara materi. Oleh karena itu merupakan kewajiban bagi setiap Negara untuk melakukan pengendalian pencemaran dan kerusakan lingkungan hidup dengan menggunakan instrument perizinan dan kebijakan lingkungan.

${ }^{3}$ Suparto Wijoyo, Penyelesaian Sengketa Lingkungan, Airlangga University Press, 1999, hlm. 1.
Di Indonesia upaya pengendalian dan pencegahan dampak negative kegiatan industri secara normatif telah diatur sejak dikeluarkanya Undang Undang Nomor 4 Tahun 1982 tentang Ketentuanketentuan Pokok Pengelolaan Lingkungan Hidup, yang selanjutnya disebut UULH, yang kemudian diganti dengan Undang Undang Nomor 23 Tahun 1997 tentang Pengelolaan Lingkungan Hidup, yang selanjutnya disebut UUPLH, dan terakhir diganti dengan Undang Undang Nomor 32 Tahun 2009 tentang Perlindungan dan Pengelolaan Lingkungan Hidup, yang selanjutnya disebut UUPPLH. Berdasarkan undang-undang lingkungan hidup yang pernah ada (UULH dan UUPLH), hak atas lingkungan hidup yang baik dan sehat merupakan hak yang dilindungi dan dijamin oleh norma-norma hukum lingkungan, serta meletakan tanggung jawab dan tanggung gugat kepada pelaku perusak dan atau pencemar lingkungan.

Mengenai perlindungan terhadap hak atas lingkungan hidup yang baik dan sehat dalam sejarahnya pernah diatur di dalam ketentuan Pasal 5 ayat (1) UULH, Pasal 6 ayat (1) ỤUPLH, dan yang terahir diatur di dalam ketentuan Pasal 65 ayat(1)UUPPLH, yang selengkapnya dirumuskan:"Setiap orang berhak atas lingkungan hidup yang baik dan sehat sebagai bagian dari hak asasi manusia". Pengakuan dan perlindungan hukum terhadap hak atas lingkungan hidup ini sebenarnya merupakan realisasi dari prinsip yang pertama dari Deklarasi Lingkungan Hidup 1972 atau yang lazim disebut dengan Deklarasi Stockholm 1972, Selengkapnya prinsi pertama dari Deklarasin Stockholm tersebut dirumuskan::" Man has the the fundamental right to freedom, equality and adequate conditions of life, in an environment of a quality that permits a life of dignity and well being and he bears a solemn responsibility to protect and improve the environment for present and future generations... ${ }^{4}$, yang selanjutnya menurut prinsip ini hak atas lingkungan hidup disejajarkan dengan hak asasi manusia dan harus memperoleh perlindungan hukum secara memadai dalam konstitusi Negara. Hak dalam konsepsi hukum barat disebut subyektif right, memiliki dua fungsi sekaligus, yaitu fungsi untuk mempertahankan hak terhadap gangguan dari pihak

${ }^{4}$ The National Environment Protection Council, Philippine Environmental Law, Vol.1. Ministry of Human Settlements, Quezon City, 1981, hlm.9. 
lain, dan sekaligus memberikan hak untuk mengajukan klaim atau tuntutan dari pihak lain atas terganggunya hak tersebut.

Selanjutnya mengenai bentuk perlindungan hak atas lingkungan hidup yang baik dan sehat tersebut, melalui undang-undang Indonesia telah memberikan jaminan perlindungan dalam bentuk hak untuk mengajukan tuntutan atau klaim atas pelanggaran tersebut, dan hak ini selanjutnya diatur di dalam ketentuan Pasal 65 ayat (5) Undang Undang Nomor 32 Tahun 2009 tentang Perlindungan dan Pengelolaan Lingkungan Hidup, yang dirumuskan:'Setiap orang berhak melakukan pengaduan akibat dugaan pencemaran dan/atau perusakan lingkungan hidup". Pelanggaran terhadap hak atas lingkungan hidup yang baik dan sehat dapat dikategorikan sebagai pelangaran hukum atas hak seseorang, baik dalam konteks hukum perdata, maupun hukum pidana, sehingga pelanggaran hak atas lingkungan hidup yang baik dan sehat sebagai akibat kegiatan industri, melahirkan sengketa antara yang dilanggar hak atas lingkungan hidupnya dengan pihak industri yang melakukan pencemaran. Secara normatifpengertian sengketa lingkungan hidup dapat dilihat dalam ketentuan Pasal 1 angka 25, yang dirumuskan: "Sengketa lingkungan hidup adalah perselisihan antara dua pihak atau lebih yang timbul dari kegiatan yang berpotensi dan/atau telah berdampak pada lingkungan hidup.

Memperhatikan ketentuan tersebut di atas dapat disimpulkan bahwa sengketa lingkungan menurut UUPPLH tidak selalu terjadi setelah adanya pencemaran, sebab dengan mengutip kalimat "kegiatan yang berpotensi dan/atau telah berdampak", maka sengketa lingkungan sudah dapat terjadi apabila kegiatan tersebut diperkirakan berpotensi menimbulkan dampak yang merugikan terhadap pihak lain atau benar-benar sudah menimbulkan dampak yang merugikan terhadap pihak lain. Permasalahanya terkait dengan kegiatan yang diperkirakan berpotensi dampak, kemungkinan kesulitanya terkait dengan pembuktian atas dalil-dalil gugatan yang diajukan oleh pihak yang akan dirugikan akibat rencana kegiatan tersebut. Bagaimana dapat membuktikan sebuah rencana kegiatan yang diperkrakan memiliki potensi mencemari atau merusak lingkungan hidup, sebagai bahan perbandingan dalam delik pidana lingkungan pada umumnya menganut delik pidana materiil, sebuah perbuatan pencemaran lingkungan hanya dapat dianggap sebagai tindak pidana apabila akibat tersebut telah menimbulkan akibat yang dapat dirasakan secara nyata merugikan orang lain. Apabila potensi pecemaran tersebut sudah dapat melahirkan sengketa, maka ketika gugatan diajukan kesulitanya terletak pada dalil gugatan dan atau pembuktian atas dalil-dalil gugatan yang diajukan penggugat.

\section{Rumusan Permasalahan}

Berdasarkan latar belakang permasalahan sebagaimana diurakan di muka, maka permasalahan atau isu hukum yang dikemukakan dalam penelitian ini sebagai berikut:"Bagaimanakah dinamika dan permasalahan penyelesaian sengketa lingkungan hidup menurut hukum positif di Indonesia?

\section{Metode Penelitian}

Jenis penelitian ini merupakan penelitian hukum normatif, dengan demikian pendekatan permasalahan yang digunakan adalah pendekatan peraturan perundang-undangan (statute approach), yaitu pendekatan yang menitik beratkan pada pengkajian peraturan perundang-undanan yang berkaitan dengan lingkungan hidup, khususnya tentang penyelesaian lingkungan hidup. Selanjutnya mengenai bahan hukum yang digunakan meliputi bahan hukum primer yang terdiri dari UUPPLH, dan peraturan pelaksanaanya, serta peraturan perundangan yang terkait dengan penyelesaian sengketa, serta didukung dengan bahan hukum sekunder yang terdiri dari bahan-bahan pustaka yang memberi penjelasan bahan hukum primer. Pengumpulan bahan hukum dilakukan dengan menggunakan system kartu, dengan teknik pegolahan dengan cara memilih dan memilah bahan-bahan hukum sesuai dengan sifat bahan hukumnya. Analisis yang digunakan adalah analisi diskripsi atau diskriptif analisis, yang sifatnya menjelaskan permasalahan yang dikemukakan secara analitis dengan menggunakan bahan-bahan hukum yang tersedia.

\section{Kerangka Teoritik}

Hak atas lingkungan hidup yang baik dan sehat sebagaimana ditentukan dalam Pasal 65 ayat (1) Undang Undang Nomor 32 Tahun 2009 tentang Perlindungan dan Pengelolaan Lingkungan Hidup, merupakan hak setiap orang sebagai hak yang setara dengan hak asasi, dan memberikan konsekuensi 
bagi yang memiliki untuk mempertahankanya. Menurut Siti Sundari Rangkuti ${ }^{5}$, hak atas lingkungan hidup yang baik dan sehat perlu dimengerti secara yuridis dan diwujudkan melalui saluran sarana hukum, sebagai upaya perlindungan hukum bagi masyarakat di bidang lingkungan hidup. Sehubungan dengan hal tersebut, maka dalam ketentuan Pasal 67 mewajibkan bagi setiap orang untuk memelihara kelestarian fungsi lingkungan hidup, serta mengendalikan pencemaran dan/atau kerusakan lingkungan hidup. Konsekuensi dari hak atas lingkungan hidup dan kewajiban untuk menjaga kelestarian fungsi lingkungan tersebut, maka dalam Undang Undang Nomor 32 Tahun 2009 tentang Perlindungan dan Pengelolaan Lingkungan Hidup, juga menyediakan sarana hukum bagi setiap orang untuk mempertahankan haknya atas lingkungan hidup yang baik dan sehat tersebut melalui sarana yang disediakan, baikmelalui sarana litigasi maupun yang non litigasi.

Dalam ajaran perbuatan melanggar hukum, setiap perbuatan yang melanggar hak, dan akibat pelanggaran hak tersebut merugikan orang lain, maka terhadap pihak yang melakukan pelanggaran tersebut diwajibkan untuk membayar ganti kerugian terhadap pihak lan yang dirugikan tersebut. Hal ini tertuang di dalam ketentuan Pasal 1365 B.W., yang dirumuskan:'Tiap-tiap perbuatan melanggar hukum, terhadapnya diwajibkan untuk membayar ganti kerugian terhadap pihak yang dirugikan". Lazimnya penyelesaian gugat ganti kerugian atas dasar perbuatan melanggar hukum diselesaikan melalui lembaga peradilan, namun demikian penyelesaian sengketa ganti rugi melalui pengadilan (proses litigasi) tidak selalu dapat diselesaikan dengan baik, mengingat banyak kelemahan yang mendasar pada metode penyelesaian tersebut.

Dalam kaitannya dengan kelemahan penanganan perkara gugatan ganti rugi melalui proses litigasi di Indonesia, M. Yahya Harahap menyatakan ${ }^{6}$,

Di Indonesia memerlukan rentang waktu 7-12 tahun, atau 5-15 tahun, bahkan 15-20 tahun, di samping itu juga ada yang memakan tempo 5-6 tahun. Tempo tahapan penelesaian senketa terpola bervariasi secara hirarchis: padatingkat peradilan pertama 1-2 tahun, banding 1-2 tahun, kasasi 1-3 tahun, dan Peninjauan Kembali 2-3

${ }^{5}$ Siti Sundari Rangkuti, Hukum Lingkungan dan Kebijaksanaan Lingkungan Nasional, Airlangga University Press, 996, hlm. 251.

${ }^{6}$ M. Yahya Harahap, Ada Krisis Pada Dunia Peradilan Kita, Kompas, 16 Juli, 1997. tahun. Kelambatan itu sulit dihilangkan, karena semua perkara dimintakan banding dan kasasi. Bahkan permintaan Peninjauan Kembali menjadi mode, Masyarakat pencari keadilan sudah dirasuki sikap irasional, mereka tidak mempersoalkan apakah putusan yang dijatuhkan benar dan adil. Kekalahan dianggap ketidak adilan oleh karena itu segala upaya yang dibenarkan undang-undang dmanfaatkan. Pemanfaatanya ternyata kadang-kadang mengandung itiked buruk sekedar untuk menjegal pelaksaan eksekusi. Dalam keadaan seperti benar-benar sistem peradilan tidak mampu melenyapkan bahkan memperkecil upaya penggunaan upaya hukum yang diselimuti itikad buruk.Kesimpulannya sitem litigasi memang potensial menyelesaikan sengketa.

Dibandingkan dengan penyelesaian litigasi, metode non litigasi memiliki kelebihan-kelebihan yang selama ini justru menjadi harapan semua masyarakat, khususnya pencari keadilan. Hal ini dapat dilihat dalam beberapa indikator dari kelebihan penyelesaian sengketa melalui upaya litigasi $^{7}$ :

- merupakan metode penyelesaian sengketayang fleksibel dan responsive bagi para pihak yang bersengketa;

- memperluas akses masyarakat terhadap penegakan hukum dan keadilan;

- keluwesan dalam menentukan pilihan-pilahan ata alternatifyang dikehendaki para pihak, baik metode penyelesaian, waktu dan tempat penyelesaian, maupun pemenuhan hak dan kewajiban masing-masing pihak;

- leih cepat, tidak prosedural;

- biaya sesuai dengan kesepakatan bersama;

- tidak menimbulkan permusuhan antara pihak yang bersegketa;

- kerahasiaan para pihak terjaga;

- prosedur yang rumit dapat dihidari;

- para pihak bebas menentukan pilahan pihak ketiga netral seuai dengan kriteria yang diinginkan.

Kelemahan-kelemahan penyelesaian sengketa melalui litigasi tersebut melahirkan asumsi, bahwa penyelesaian melalui lembaga peradilan bukan merupakan forum terbaik untuk menyelesaikan sengketa lingkungan. Oleh karena itu banyak sarjana yang mengkaji dan mengembangkan metode lain yang lebih konperenship dalam penyelesaian

${ }^{7}$ Disarikan dari Makalah Bahan Pelatihan Mediasi, yang diselengarakan di Jakarta, Medio Juni, 2008. 
sengketa ligkungan sebagai alternative. Sistem yang diperkenalkan tersebut meliputi:mediasi, konsiliasi, dan arbitrasi ${ }^{8}$.

Di dalam pustaka hukum lingkungan, diantara metode-metode sebagaimana disebtan di atas, metode "mediasi" sebagai salah satu cara untuk menyelesaiakan sengketa lingkungan yang paling sederhana. Cormick dan Patton mendefinisikan mediasi sebagai:" Mediation is a voluntary process in which those involved in a dispute jointly axplore and reconcicle their defference. The mediator has no authority to impose settlements. His or her strength lies on the ability to assist the parties in resolving their owen differences. The mediated dispute is sttled when parties themselves reach what they consider to be workable solution'. Selanjutnya Gresser menyatakan ${ }^{10}$...Parties to mediation usually memorialize their agreement in a written mediation agreement. Because he document is deemed a contract under art 695 of the Civil Code, once the parties agree to be bound by a particular mediation settlement they lose their right to litigate their dispute. Parties, of course always retain the right to litigate should a settlement break down.

Di Indonesia, meskipun metode mediasi merupakan metode penyelesaian sengketa yang berasal dari konsep luar, namun secara factual penyelesaian mediasi yang esensinya musyawarah mufakat telah menjadi asas dalam penyelesaian sengketa yang dianut oleh sebagian besar masyarakat. Menurut Takdir Rachmadi, mediasi ini dapat dipertimbangkan penggunaanya sebagai salah satu alternative penyelesian sengketa lingkungan ${ }^{11}$.

Penegakan hukum lingkungan dapat dilakukan baik secara preventif, maupun represif. Bersifat preventif berarti pengawasan aktif dilakukan terhadap kepatuhan terhadap peraturan tanpa kejadian langsung yang menggambarkan peristiwa konkrit yang menimbulkan sangkaan bahwa peraturan hukum telah dilanggar. Penegak hukum dalam hal demikian adalah pejabat/aparat pemerintah yang

${ }^{8}$ Siti Sundari Rangkuti, Hukum Lingkungan dan Kebijaksanan Lingkungan Daląm Proses Pembangunan Hukum Nasional Indonesia, Airlangga University Press, 1991, hlm. 180-182.

${ }^{9}$ Takdir Rachmadi, Environmental Mediation The North American Experiences and Potential Applicapability, Thesis, 1989, hlm. 71.

${ }^{10}$ Siti Sundari,Op.Cit., 181.

${ }^{11}$ Takdir Rachmadi, Op.Cit., hlm. 10. berwenang memberi izin dan mencegah terjadinya pencemaran lingkungan. Penegakan hukum yang bersifat represif dilakukan dalam hal adanya perbuatan yang melanggar peraturan. Penindakan secara pidana umumnya selalu menyertai pelanggaran peraturan dan biasanya tidak dapat meniadakan akibat pelanggaran tersebut. Untuk menghindari penindakan pidana secara berulang, pelaku sendiri yang harus menghentikan keadaan itu. Mengenai penegakan hukum lingkungan keperdataan hendaknya dibedakan dari upaya penyelesaian sengketa dengan cara gugatan lingkungan yang sifatnya individual. Gugatan perdata yang dimaksud dalam penegakan hukum lingkungan dilakukan oleh penguasa apabila sarana penegakan hukum administratifkurang memadai.

\section{PEMBAHASAN}

Pengaturan penyelesaian sengketa lingkungan hidup sebenarnya telah diakomodir di dalam hukum positifdi Indonesia sejak sejak berlakunya Undang Undang Nomor 4 Tahun 1982 tentang Ketentuan Ketentuan Pokok Pengelolaan Lingkungan Hidup. Hal ini dapat dilihat di dalam ketentuan Pasal 20 ayat (1) dan ayat (2), yang selengkapnya dirumuskan:

(1) Berdasarkan uraian Barang siapa merusak dan atau mencemarkan lingkungan hidup, memikul tanggung jawab dengan kewajiban membayar ganti kerugian kepada pihak penderita yang telah dilanggar haknya atas lingkungan hidup yang bai dan sehat;

(2) Tata cara pengaduan oleh penderita oleh penderita, tata cara penelitian oleh tim tentang bentuk, jenis dan besarnya kerugian, serta tata cara penentuan ganti kerugian diatur dengan peraturan perundang-undangan.

Berdasarkan ketentuan ayat (1) dan ayat (2) di atas dapat disimpulkan, bahwa penyelesaian sengketa lingkungan menurut UULH tidak arus dilakukan melalui litigasi dengan mengajukan gugatan ganti kerugian ke Pengadilan. Ketentuan pasal tersebut justru membuka peluang bagi digunakannya upaya-upaya di luar jalur hukum (non litigasi) sebagai metode penyelesaian sengketa lingkungan. Namun demikian sampai dengan dicabutnya UULH, dan diganti dengan UUPLH, peraturan pelaksanaan tersebut masih dalam bentuk "Rancangan Peraturan Pemerintah (RPP) tentang 
Tata Cara Gugatan dan Penentuan Ganti Kerugian". Tidak segera dibentuknya Peraturan Pemerintah tersebut menyebabkan penyelesaian sengketa lingkungan pada saat berlakunya UULH tidak dapat diselesaikan dengan baik, bahkan di Surabaya ada hakim yang menolak mengadili gugatan pencemaran oleh Lembaga Swadaya Masyarakat (LSM) terhadap perusahaan swasta dengan alasan gugatan tersebut masih premature, karena peraturan pemerintahnya belum dibentuk.

Sebenarnya alasan hakim menolak perkara demikian tidak tepat, mengingat pada saat itu berlaku Undang Undang Nomor 14 Tahun 1970 tentang Kekuasaan Kehakiman, yang dalam ketentuan Pasal 14 jo. Pasal 27 memungkinkan bagi hakim untuk menggali, mencari, dan menemukan nilai-nilai hukum yanghidup di dalam masyarakat melalui rechtvinding. Mendasarkan ketentuan pasal tersebut seharusnya gugatan ganti kerugian tersebut sebenarnya dapat diselesaikan dengan menggunakan ketentuan Pasal 1365 B.W., tentang perbuatan melanggar hukum (onrechtmatigedaad), meskipun penggugat diwajibkan untuk membuktikan dalil-dalil gugatanya, karena ketentuan pasal tersebut menganut prinsip liability based on fault atau tanggung gugat atas dasar pembuktian kesalahan.

Permasalahan lain terkait dengan penyelesaian lingkungan menurut UULH, sehubungan dengan penjelasan ketentuan Pasal 20 ayat (2), yang menyatakan bahwa, pembentukan tim tersebut akan dibentuk untuk tiap-tiap kasus. Hal ini dapat dipahami dalam penjelasan tersebut yang selengkanya disebutkan:

\begin{abstract}
Bentuk dan jenis kerugian akibat perusakan dan pencemaran akan menetukan besarnya kerugian dilakukan oleh yang dibentuk oleh Pemerintah. Penelitian meliputi bidang ekologi, medis, social budaya dan lain-lain yang diperlukan. Tim yang terdiri dari pihak penderita atau kuasanya, pihak pencemar atau kuasanya, dan unsur pemerintah dibentuk untuk tiap-tiap kasus. Jika diperlukan dapat diangkat tenaga ahli untuk menjadi anggota tim. Bilamana tidak dapat tercapai kata sepakat dalam batas waktu tertentu, maka penyelesaiannya dilakukan melalui pengadilan negeri.
\end{abstract}

Berdasarkan kutipan diatas, dapat disimpulkan bahwa penyelesaian sengketa lingkungan di luar pengadilan diselesaikan melalui tim yang disebut dengan tim tri pihak (tim tripartite), dan untuk tiaptiap kasus akan dibentuk tim yang menyelesaikan kasus tersebut. Oleh karena itu dapat dibayangkan berapa banyak tim yang akan dibutuhkan untuk itu, jika hal demikian harus dilakukan maka penyelesian sengketa lingkungan akan lebih tidak efisien, karena tiap-tiap kasus akan diselesaikan oleh tim yang berbeda.

Mengingat kelemahan-kelemahan yang ada, tentunya di samping kelemahan tersebut di muka, maka pada tahun 1997 UULH tersebut kemudian diganti dengan Undang Undang Nomor 23 Tahun 1997 tentang Pengelolaan Lingkungan Hidup (UUPLH), dan UUPLH ini juga mengatur mengenai penyelesaian sengketa lingkungan hidup, yang diatur di dalam ketentuan Pasal 30 sampai dengan Pasal 39. Selanjutnya menurut UUPL penyelesaian sengketa lingkungan hidup dapat dilakukan dengan menggunakan dua mekanisme, yaitu melalui jalur pengadilan (itigasi) dan di luar pengadilan (non litigasi). Penyelesaian sengketa lingkungan hidup di luar pengadilan dilakukan atas dasar pilihan suka rela para pihak yang bersengketa, namun penyelesaian ini tidak berlaku bagi tindak pidana lingkungan. Apabila para pihak telah memilih penyelesaian sengketa di luar pengadilan, maka penyelesaian sengketa melalui lembaga peradilan (itigasi) hanya dapat ditempuh apabila penyelesaian non litigasi tersebut dinyatakan tidak berhasil oleh salah satu pihak atau kedua belah pihak yang bersengketa Pasal 30 UUPLH.

Penyelesaian sengketa di luar pengadilan ini dimaksudkan untuk menentukan atau mencapai kesepakatan megenai bentuk dan besarnya ganti kerugian dan/atau mengenai tindakan tertentu untuk mencegah atau menjamin terulangnya dampak negative yang merugikan tersebut. Untuk penyelesaian sengketa lingkungan di luar pengadilan ini selanjutnya dapat menggunakan pihak ketiga netral, baik yang memiliki kewenangan memutus, maupun yang tidak memiliki kewenangan memutus. Oleh karena itu penyelesaian sengketa di luar pengadilan menurut UUPLH ini lebih luas dibandingkan menurut UULH, seban menurut UUPLH upaya yang dilakukan untuk menyelesaikan sengketa dapat terdiri dari arbitrase sebagai lembaga yang memiliki kewenangan memutus, terdiri dari mediasi, dan konsiliasi, dan lembaga ini bertugas sebagai pihak yang hanya memediatori atau memfasilitasi penyelesaian sengketa tanpa wewenang memutus. Hal ini yang membedakan 
dengan penyelesaian sengketa lingkungan di luar pengadilan menurut UULH yang hanya dilakukan oleh tim tri pihak, yang tentunya tidak sama dengan penyelesaian melalui mediasi ${ }^{12}$. Mengenai pihak ketiga yang menjadi fasilitator penyelesaian sengketa lingkungan di luar pengadilan ini dapat dibentuk oleh Pemerintah dan/atau masyarakat sendiri, yang akan diatur lebih lanjut dengan peraturan pemeritah.

Selanjutnya mengenai tuntutan ganti kerugian diatur di dalam ketentuan Pasal 34, yang selengkapnya dirumuskan:

(1) Setiap perbuatan melanggar hukum berupa pencemaran dan/atau perusakan lingkungan hidup yang menimbulkan kerugian pada orang lain atau lingkungan hidup, mewajibkan penanggung jawab usaha dan/atau kegiatan untuk membayar ganti rugi dan/atau melakukan tindakan tertentu;

(2) Selain pembebanan untuk melakukan tindakan tertentu sebagaimana dimaksud pada ayat (1), hakim dapat menetapkan pembayaran uang paksa atas setiap hari keterlambatan penyelesaian tindakan tertentu tersebut.

Berdasarkan ketentuan di atas dapat disimpulkan bahwa tuntutan ganti kerugian akibat pencemaran lingkungan pada dasarnya tidak berbeda jauh dengan pada saat berlakunya UULH, namun yang perlu dicatat sehubungan dengan penjelasan Pasal 34 ayat (1) UUPLH, yang menyatakan, bahwa:"Ayat ini merupakan realisasi asas yang ada dalam hukum lingkungan hidup yang disebut asas pencemar membayar. Selain diharuskan membayar ganti rugi, pencemar dan/atau perusak lingkungan hidup dapat pula dibebani oleh hakim untuk melakukan tindakan tertentu, misalnya perintah untuk:

- Memasang atau memperbaiki unit pengolahan limbah sehingga limbah sesuai dengan baku mutu lingkungan hidup yang ditentukan;

- Memulihkan fungsi lingkungan hidup;

- Menghilangkan atau memusnahkan penyebab timbulnya pencemaran dan/atau perusakan lingkungan hidup.

${ }^{12}$ Siti Mariyani, Penyelesaian Sengketa Kali Tapak Akibat Pencemaran Industri, tidak diterbitkan, 2004, hlm. 9, yang menyatakan tim tri pihak tidak sama dengan mediasi lingkungan menurut hukum lingkungan, tetapi ada persamaanya, yaitu salah satunya adalah penyelesaian sengketa di luar pengadilan.
Substansi penjelasan pasal ini menunjukan ketidak pahaman perancang dan pembentuk UUPLH tentang konsep pencemar membayar (the poluter pays principles) dan tidak mampu membedakan dengan konsep ganti rugi, sebab prinsip ini sama dengan prinsip yang memperbolehkan melakukan pencemaran asalkan membayar pencemaran, prinsip demikian sudah tidak relevan dan ditinggalkan oleh Negara-negara maju, sedangkan ganti rugi bukan merupakan pembayaran biaya pencenaran, melainkan ganti kerugian akibat perbuatan pencemaran, dengan harapan tidak akan terulang kembali pencemaran tersebut, prinsipnya tidak boleh mencemari, dan esensinya ganti rugi bukan biaya pencemaran untuk mencemari.

Selain pembebanan untuk melakukan tindakan tertentu, hakim dapat menetapkan pembayaran uang paksa atas setiap hari keterlambatan penyelesaian tindakan tertentu tersebut, dan pembayaran uang paksa dimaksudkan demi pelestarian fungsi lingkungan hidup. Penanggungjawab usaha dan/atau kegiatan usaha dan kegiatannya menimbulkan dampak besar dan penting terhadap lingkungan hidup, yang menggunakan bahan yang berbahaya dan beracun, dan/atau menghasilkan limbah bahan berbahaya dan beracun, bertanggungjawab secara mutlak atas kerugian yang ditimbulkan, dengan kewajiban membayar ganti rugi secara langsung dan seketika pada saat terjadinya pencemaran dan/atau perusakan lingkungan hidup. Penanggung jawab usaha dan/atau kegiatan dapat dibebaskan dari kewajiban membayar ganti rugi sebagaimana dimaksud di atas, jika yang bersangkutan dapat membuktikan bahwa pencemaran dan/atau perusakan lingkungan disebabkan salah satu alasan di bawah ini:

a. adanya bencana alam atau peperangan;

b. adanya keadaan terpaksa di luar kemampuan manusia; atau

c. adanya tindakan pihak ketiga yang menyebabkan terjadinya pencemaran dan/atau perusakan lingkungan hidup.

Alasan-alasan diatas merupaka perkecualian dari tanggung gugat pelaku pencemar, sepanjang alasan-alasan tersebut dapat dibuktikan kebenarannya, sehingga alasanalasan tersebut dapat dijadikan 
alasan pemaaf atas kesalahan penggugat yang telah diänggap mencemari lingkungan hidup.

Pengertian bertanggungjawab secara mutlak, yakni unsur kesalahan tidak perlu dibuktikan oleh pihak penggugat sebagai dasar pembayaran ganti kerugian. Ketentuan ini merupakan lex specialis dalam gugatan tentang perbuatan melanggar hukum pada umumnya. Besarnya nilai ganti rugi yang dapat dibebankan terhadap pencemar atau perusak lingkungan hidup dapat ditetapkan sampai batas waktu tertentu. Maksud sampai batas waktu tertentu adalah jika menurut penetapan peraturan perundangundangan yang berlaku, ditentukan keharusan asuransi bagi usaha dan/atau kegiatan yang bersangkutan atau telah tersedia dana lingkungan hidup. Tenggang waktu daluwarsa hak penggugat untuk mengajukan gugatan ke pengadilan mengikuti tenggang waktu sebagaimana diatur dalam ketentuan Hukum Acara Perdata yang berlaku, dan dihitung sejak korban mengetahui adanya pencemaran dan/ atau perusakan lingkungan hidup. Ketentuan mengenai tenggang daluwarsa sebagaimana dimaksud di atas tidak berlaku terhadap pencemaran dan/atau perusakan lingkungan hidup yang diakibatkan oleh usaha dan/atau kegiatan yang menggunakan bahan berbahaya dan beracun dan/atau menghasilkan limbah beban berbahaya dan beracun ${ }^{13}$. Tata cara pengajuan gugatan dalam masalah lingkungan hidup oleh penggugat mengacu tunduk pada Hukum Acara Perdata yang berlaku. Sedangkan sarana administratif dapat bersifat preventif dan memiliki tujuan menegakkan peraturan perundang-undangan lingkungan (misalnya: undang-undang, peraturan pemerintah, keputusan menteri perindustrian, keputusan gubernur, keputusan walikota dan sebagainya).

Tepat pada tanggal 3 Oktober 2009 diundangkan Undang Undang Nomor 32 Tahun 2009 tentang Perlindungan dan Pengelolaan Lingkungan Hidup, yang selanjutnya disingkat UUPPLH, dan sekaligus undang-undang ini menggantikan UUPLH. Dalam kaitanya dengan penyelesaian sengketa lingkungan, UUPPLH ini pada prinsipnya tidak jauh berbeda dengan UUPLH, sebab di dalam UUPPLH juga mengatur mekanisme penyelesaian sengketa yang hampir samä dengan UUPLH. Sebab dalam UUPPLH juga mengenal mekanisme penyelesaian

${ }^{13}$ Siti Mariyani, Op.Cit. 14 Siti Sundari Kangkuti, Op. Cit., hlm., 192 sengketa lingkungan baik dengan mekanisme atau jalur pengadilan, maupun mekanisme di luar jalur pengadilan. Hal ini dapat dilihat pada ketentuan Pasal 84 yang dirumuskan:

(1) Penyelesaian sengketa lingkungan hidup dapat ditempuh melalui pengadilan dan di luar pengadilan;

(2) Pilihan penyelesaian sengketa lingkungan hidup dilakukan secara suka rela oleh para pihak yang bersengketa;

(3) Gugatan melalui pengadilan hanya dapat ditempuh pabila upaya penyelesaian sengketa di luar pengadilan yang dipilih dinyatakan tidak berhasil oleh salah satu atau para pihak yang bersegketa.

Penyelesaian sengketa lingkungan di luar pengadilan menurut UUPPLH ini juga bertujuan untuk mencapai kesepakatan mengenai:

a. bentuk dan besarnya ganti rugi;

b. tindakan pemulihan akibat pencemaran dan/ ataun perusakan lingkungan;

c. tindakan tertentu untuk menjamin tidak akan terulangnya pencemaran dan/atau perusakan; dan/atau

d. tindakan untuk mencegah timbulnya dampak negatifterhadap lingkungan hidup.

Mengenai ketentuan sengketa yang diselesaikan melalui mekanisme di luar pengadilan ini juga tidak berlaku bagi tindak pidana lingkungan yang diatur dalam undang-undang ini. Hanya saja dalam kaitanya dengan jasa pihak ketiga netral yang digunakan sebagai penengah berbeda dengan yang diatur di dalam UUPLH, jika dalam UUPLH didasarkan atas lembaga yang berwenang mengambil keputusan dan lembaga yang tidak berwenang mengambil keputusan, maka di dalam UUPPLH secara tegas disebutkan, bahwa yang jasa pihak ketiga yang dapat menjadi penengah dalam penyelesaian sengketa lingkungan hidup ditentukan secara jelas yaitu jasa mediator dan/atau abiter, selanjutnya lihat Pasal 85 ayat (3). Menarik untuk dicermati kalimat ...mediator dan/atau arbiter.., dengan kalimat tersebut maka dapat dikatakan, bahwa jasa mediator dan atau arbiter dapat digunakan secara bersama-sama atau sendiri-sendiri dalam sebuah penyelesaian sengketa lingkungan hidup, hanya saja yang harus 
diatur lebih lanjut adalah bagaimana mekansme penggunaan metode jasa pihak ketiga dalam penyelesaian sengketa lingkungan tersebut, mana yang didahulukan dan bagaimana tata caranya. Selanjutnya mengenai jasa pihak ketiga netral ini dapat dibentuk oleh masyarakat sendiri, hanya saja dalam UUPPLH ditentukan keterlibatan Pemerintah dan Pemerintah Daerah, namun yang perlu mendapat perhatian menyangkut bagaimana peran atau sejauh mana keterlibatan pemerintah dalam memfasilitasi pementukan pihak ketiga netral yang menjadi fasilitator penyelesaian sengketa lingkungan hidup di luar pengadilan ini. Tentunya hal ini harus sabar menunggu, sebab mengenai lembaga penyedia jasa pihak ketiga penyelesaian sengketa di luar pengadilan ini akan diatur lebih lanjut dengan Peraturan Pemerintah, dan dalam ketentuan Pasal 126 UUPPLH, disebutkan bahwa Peraturan Pelaksanaan yang diamanatkan dalam Undang-undang ini ditetapkan paling lama 1 (satu) tahun terhitung sejak undang-undang ini diberlakukan.

Selanjutnya mengenai penyelesaian sengketa melalui jalur pengadilan (litigasi), menurutUUPPLH ini diatur di dalam ketentuan Pasal 87 sampai dengan Pasal 93. Mengenai gugatan ganti rugi dan Pemulihan Lingkungan diatur di dalam ketentuan Pasal 87 yang selengkapnya dirumuskan:

(1) Setiap penanggung jawab usaha dan/atau kegiatan yang melakukan perbuatan melanggar hukum berupa pencemaran dan/atau perusakan lingkungan hidup yang menimbulkan kerugian pada orang lain atau lingkungan hidup membayar ganti rugi dan/atau melakukan tindakan tertentu;

(2) Setiap oang yang melekukan pemindahtanganan, pengubahan sifat dan bentuk usaha, dan/atau kegiatan dari suatu badan usaha yang melanggar hukum tidak melepaskan tanggung jawab hukum dan/atau kewajiban badan usaha tersebut;

(3) Pengadilan dapat menetapkan pembayaran uang paksa terhadap setiap hari keterlambatan atas pelaksanaan putusan pengadilan;

(4) Besarnya uang paksa diputuskan berdasarkan peraturan perundang-undangan.

Di dalam UUPPLH juga belum ada perubahan terhadap persepsi pembentuk undang-undang ini mengenai apa yang disebut dengan ganti rugi, sebab di dalam penjelasan Pasal 87 ayat (1) UUPPLH juga masih menyebutkan redaksi, bahwa ketentuan dalam ayat ini merupakan reaisasi asas pencemar membayar. Tidak jelas apakah konseptornya sama atau memang pembentuk undang-undang ini tidak berusaha memahaminya. Sesungguhnya apabila pembentukan undang-undang ini dimulai dengan naskah akademik kesalahan tersebut tidak akan terulang kembali, tetapi bagaimanapun hal itu sudah terlanjur diundangkan, yang secara yuridis mengikat bagi seluruh masyarakat meskipun hal tersebut sebenarnyakurang tepat, sebab pencemar akan bebas mencemari yang penting membayar ganti kerugian.

Mengenai ketentuan Pasal 91 sebenarnya merupakan ketentuan pasal yang mengatur tentang tanggung gugat juga, tetapi ketentuan pasal tersebut khusus mengatur mengenai tanggung gugat yang dilakukan oleh Masyarakat, yang lazim dikenal dengan hak gugat masyarakat. Ketentuan Pasal 91 tidak secara tegas menunjuk mekanisme penyelesaian sengketa lingkungan antara masyarakat dengan pelaku pencemaran/pencemar, demikian juga dengan ketenuan Pasal 92 yang mengatur tentang Hak Gugat Organisasi Lingkungan (OLH), juga tidak mengatur mengenai mekanisme gugatannya, apakah penyelesaianya dapat dilakukan dengan menggunakan penyelesaian sengketa di luarpengadilan, sehingga sama dengan yang telah dijelaskan pada uraian terdahulu. Namun yang pasti hak gugat masyarakat hanya dapat dilakukan apabila terdapat kesamaan fakta atau peristiwa, dasar hukum, serta jenis tuntutan diantara kelompok atau anggota kelompok. Sedangkan gugatan Organisasi Lingkungan Hidup $(\mathrm{OLH})$ hanya dapat dilakukan dengan ketentuan apabila organisasi lingkungan hidup tersebut memenuhi persyaratan sebagai berikut:

a. Berbentuk badan hukum;

b. Menegaskan di dalam anggaran dasarnya bahwa organisasi tersebut didirikan untuk kepentingan pelestarian fungsi lingkungan hidup; dan

c. Telah melaksanakan kegiatan nyata sesuai dengan anggaran dasarnya paling singkat 2 (dua) tahun.

Permasalahanya apakah masyarakat dan organisasi lingkungan hidup dapat menyelesaiakan sengketanya melalui metode penyelesaian sengketa di luar pengadilan, tentunya perlu diperjelas. Namun 
apabila berpedoman pada pengertian subyek dalam hukum lingkungan, bahwa masyarakat maupun organisasi lingkungan merupakan subyek hukum lingkungan, maka secara otomatis juga dapat menggunakan metode tersebut, apabila dilihat ke belakang dalam penjelasan Pasal 5 ayat (1) UULH dulu, yang dimaksud orang adalah orang perorang, kelompok orang dan badan hukum, baik badan hukum perdata, maupun badan hukum publik, hanya saja terdapat perbedaan tuntutanya saja, untuk Organisasi Lingkungan Hidup hanya dapat mengajukan tuntutan untuk kepentingan pelestarian fungsi lingkungan hidup, tanpa diperbolehkan mengajukan gugatan ganti kerugian, kecuali hanya untuk pengeluaran riil terkait dengan biaya gugatan.

\section{VI.Penutup}

\section{Kesimpulan}

Berdasarkan uraian pembahasan permasalahan yang dikemukakan di muka, maka dapat ditarik kesimpulan sebagai berikut:

a. Penyelesaian sengketa lngkungan hidup setelah berlakunya UUPLH dan UUPPLHH mengalami perubahan yang prinsipiil, sebab telah diatur dengan jelas, bahwa penyelesian sengketa lingkungan hidup dapat ditempuh dengan menggunakan dua mekanisme, yaitu dengan menggunakan metode litigasi dan non litigasi. Pada penyelesaian segketa lingkungan non litigasi pada UUPLH dilakukan dengan menggunakan lembaga yang berwenang memutus dan lembaga yang tidak memiliki kewenangan memutus, sehingga penyelesaianya dapat menggunakan mediasi, arbitrase, maupun konsiliasi. Sedangkan penyelesaian sengketa lingkungan non litigas menurut UUPPLH dengan tegas disbeutkan menggunakan mediasi dan/atau arbitrase, namun tidak jelas bagaimana mekanismenya sebab masih menunggu peraturan pelaksanaanya.

b. Mengingat peraturan pelaksanaan tentang penyelesaian sengketa lingkungan dengan meng- gunakan prosedur litigasi belum ada peraturan pelaksanaanya, maka penyelesaianya menggunakan ketentuan yang lazim berlaku di dalam masyarakat dalam menuntut ganti rugi, yaitu ketentuan Pasal 1365 BW tentang perbuatan onrechtmatigedaad, sehingga penggugat dibebani kewajiban membuktikan dalil-dalil gugatanya, sebab pasal ini menganut prinsip $l i$ ability based on fault atau tanggung gugat atas dasar pembuktian kesalahan, dan mekanismenya menggunakan mekanisme sebagaimana yang berlaku di dalam hukum acara perdata.

\section{Saran}

a. Agar supaya tidak terjadi kesimpang siuran dalam pelaksanaan penelesaian sengketa lingkungan hidup, maka secepatnya peraturan pelaksanaan UUPPLH ini seyoyanya segera dibentuk sesuai dengan amanat yang telah ditentukan di dalam ketentuan Pasal 126, sebab sengketa-sengeketa hukum lingkungan baik kualitas maupun kuantitasnya semakin meningkat seiring dengan kebijakan pengelolaan lingkungan hidup yang terus dilakukan. Keterlambatan pembentukan peraturan pelaksanaan UUPPLH akan menyebabkan terganggunya aktifitas pengelolaan lingkungan hidup di Indonesia, sebab undang-undang yang lama sudah dicabut dan dinyatakan tidak berlaku.

b. Mengingat selama ini pelaksanaan tata cara penuntutan ganti kerugian akibat pencemaran lingkungan, diberlakukan ketentuan Pasal 1365 B.W., sedangkan pasal tersebut menganut system tanggung gugat atas dasar pembuktian kesalahan (liability based on fault), maka seyogyanya segera dibentuk tata cara yang secara khusus mengatur gugatan ganti kerugian akibat pencemaran lingkungan, sehingga korban penderita pencemaran memperoleh perlindungan hukum sebagaimana mestinya. 


\section{DAFTAR PUSTAKA}

\section{Buku}

Airef Nurdu'a M., Nursyam B. Sudharsono, Hukum Lingkungan: Perundang-Undangan Serta Berbagai Masalah Dalam Penegakannya, Citra Aditya Bakti, Bandung, 1993.

Daud Silalahi, Hukum Lingkungan :Dalam Sistem Penegakan Hukum Lingkungan Indonesia, Alumni, Bandung, 1992

M.Yahya Harahap, Ada Krisis Pada Dunia Peradilan Kita, Kompas, 16 Juli,1997.

Suparto Wijoyo, Penyelesaian Sengketa Lingkungan, Airlangga University Press, 1999.

Siti Sundari Rangkuti, Hukum Lingkungan dan Kebijaksanaan Lingkungan Nasional, Airlangga University Press, 996.

Siti Mariyani, Penyelesaian Sengketa Kali Tapak Akibat Pencemaran Industri, tidak diterbitkan, 2004.
The National Environment Protection Council, Philippine Environmental Law, Vol.1. Ministry of Human Settlements, Quezon City, 1981.

Takdir Rachmadi, Environmental Mediation The North American Experiences and Potential Applicapability, Thesis, 1989.

Bahan Pelatihan Mediasi, Makalah, Jakarta, Medio Juni, 2008.

\section{Peraturan Perundang-undangan}

Undang Undang Dasar 1945 sebelum maupun setelah perubahan

Undang Undang Nomor 4 Tahun 1982 tentang Ketentuan Pokok Pengelolaan Lingkungan Hidup

Undang Undang Nomor 23 Tahun 1997 tentang Pengelolaan Lingkungan Hidup

Undang Undang Nomor 32 Tahun 2009 tentang Perlindungan dan Pengelolaan Lingkungan Hidup 
